OPEN ACCESS

Edited by:

Nikos D. Lagaros,

National Technical University of

Athens, Greece

Reviewed by:

Vito Michele Casamassima, University of Basilicata, Italy

Georgios S. Papavasileiou,

University of the Highlands and

Islands, United Kingdom

*Correspondence:

Giovanni Chiumiento

giovanni.chiumiento@unina.it

Specialty section:

This article was submitted to

Earthquake Engineering,

a section of the journal

Frontiers in Built Environment

Received: 17 February 2019

Accepted: 06 June 2019

Published: 02 July 2019

Citation:

Chiumiento G and Formisano A (2019) Simplified and Refined Analyses for Seismic Investigation of Historical

Masonry Clusters: Comparison of Results and Influence of the Structural Units Position

Front. Built Environ. 5:84 doi: 10.3389/fbuil.2019.00084

\section{Simplified and Refined Analyses for Seismic Investigation of Historical Masonry Clusters: Comparison of Results and Influence of the Structural Units Position}

\author{
Giovanni Chiumiento* and Antonio Formisano \\ Department of Structures for Engineering and Architecture, University of Naples Federico II, Naples, Italy
}

The goal of this work is the assessment of the seismic vulnerability of building clusters within the historical center of Arsita (Teramo, Italy), damaged by the 2009 L'Aquila earthquake, by comparing two different analysis procedures applied to a construction compound case study. First, the seismic vulnerability of structural units of the building compound, has been appraised using a vulnerability evaluation quick form, appropriately conceived for masonry clusters. In particular, heading and intermediate structural units, having different geometrical configuration and seismic behaviors, have been inspected using the aforementioned form, which allowed for the calculation of a synthetic vulnerability index. Starting from these indices, the probable damage suffered by the examined structural units under different grade earthquakes, have been estimated. Later, both the single structural units and the whole construction compound were modeled using the macro-element refined method provided by the 3Muri non-linear analysis software. Static non-linear analyses performed on the above-mentioned structures have provided related pushover curves, used to estimate, using the N2 method, the damage suffered under seismic actions expected at that site. Therefore, the damage of single structural units have been compared to those experienced by the same structures within the building aggregate. Finally, the results derived from the two analysis methodologies considered were compared, confirming the effectiveness of the simplest technique to predict the seismic damage and vulnerability of investigated structures.

Keywords: masonry clusters, vulnerability assessment, L’Aquila earthquake, macroelement method, pushover curves, survey form, vulnerability index method

\section{INTRODUCTION}

The assessment of the seismic vulnerability of existing buildings is a problem of particular relevance for the Italian territory, where a large part of the built heritage was not erected using anti-seismic criteria. Most of the ancient buildings in Italy are made of masonry materials with low mechanical properties, which also diminish over time due to both age and environmental factors. In addition, the rapid growth in buildings built after the Second World War, which represent the major part of Italian built heritage, was often not accompanied by planned urban development plans. It is also important to note that many Italian historical centers are often composed of clustered buildings 
resulting from several planned and vertical additions made of different materials and constructive techniques. Since they are highly exposure as cultural, architectural and historical values and are placed into medium-high hazard zones, significant social and economic losses could occur in case of earthquakes.

For these reasons, the study of historical centers in terms of seismic actions is a key issue in the field of Civil Engineering and the individuation of possible protection strategies is becoming a pressing need for administrations and designers.

Current Italian technical standards [D.M. 17/01/2018; Ministerial Decree (M.D.), 2018] deal with the high accuracy of technical prescriptions that need to be adopted for seismic protection of new constructions. On the contrary, for existing structures and even more so for historical clustered buildings, seismic behavior assessment has been only been investigated systematically a few times. In fact, such structures were mainly designed to withstand static vertical loads and static horizontal thrusts of arches and vaults, neglecting seismic actions which can provoke diffused cracks and, in worst cases, partial or global collapse. Therefore, clustered buildings are vulnerable to earthquakes and this issue should be treated in much more detail within standard building codes. Nowadays, complex methodologies based on the development of high-definition 3D numerical FEM models are often adopted for the structural assessment of historical masonry buildings (Mallardo et al., 2008; Clementi et al., 2016; Miano et al., 2017, 2018; Ramírez et al., 2019). Nevertheless, non-linear time-history analyses, commonly considered to better estimate the seismic response of buildings, require a very strong computational effort. For this reason, the current standard provides a simplified method to evaluate the seismic behavior of clustered buildings, which is only effective in cases of intermediate structural units with rigid diaphragms, where pushover analyses can be performed for each building story. This vulnerability assessment method for historical clustered buildings provided for in the building code, is often not applicable due to the lack of some important prerequisites, such as the effective connections among masonry walls and the presence of rigid horizontal floors able to distribute seismic forces uniformly among seismic-resistant elements. Indeed, in most cases flexible floors are detected, and this requires the analysis of single walls instead of the whole building. In addition, in the case of heading or angle structural units, the effects of accidental torsion should be considered. In these two latter cases, no specific provisions are provided for by the standards. Therefore, the scientific community is being pushed to find simplified applicative methods to evaluate the seismic response of structural units in masonry building clusters.

Moreover, in the case of the seismic vulnerability assessment of large urban habitats, considering that sophisticated analysis on single constructions are not required, a lot of in-situ surveys should be performed and a lot data on buildings should be acquired. Effective analysis procedures, used at a territorial scale, should be quick and should employ information from similar buildings damaged by past seismic events (Caprili et al., 2017; D'Amato et al., 2018; Fuentes et al., 2019). Therefore, three different seismic vulnerability evaluation approaches, namely Damage Probability Matrices (DPM) (Whitman et al., 1973; Grunthal, 1998; Lagomarsino and Giovinazzi, 2006;
Formisano et al., 2017a), Vulnerability Indices (VI) (Benedetti and Petrini, 1984; GNDT, 1993; Bernardini, 2000; Formisano et al., 2011; Formisano, 2017a), and Capacity Curves (CC) (ATC, 1996; Kircher et al., 1997; Magenes, 2000; Formisano, 2017b; Formisano et al., 2017b), are typically used (Calvi et al., 2006). In particular, DPM and VI methods have been validated in the damage which occurred in several areas hit by earthquakes. Some other methods based on kinematics models, involving the equilibrium of macro-elements composed of single walls or subassemblages (Bernardini et al., 1990; Giuffrè, 1993), are also used for predicting the damage to buildings within historical centers. Nevertheless, clear numerical calculation methods of clustered buildings are not provided for by the standard codes, even if in the last few years some attempts have been made to solve this problem from a theoretical-numerical (Ramos and Lourenco, 2004; Valluzzi et al., 2007; Senaldi et al., 2010; D'Ayala and Paganoni, 2011; Da Porto et al., 2013; Formisano et al., 2016; Brando et al., 2017; Cara et al., 2018; Formisano and Massimilla, 2018; Chieffo et al., 2019; Mosoarca et al., 2019; Valente et al., 2019) and experimental (Senaldi et al., 2019) point of view.

Starting from these premises, the attention of the current paper is focused on the urban center of Arsita, located in the district of Teramo, within the Abruzzo region of Italy, with the target to find a useful and reliable tool to investigate the seismic behavior of structural units within historical masonry clusters. Two different analysis procedures based on VI and CC methods have been applied to a case study of clustered buildings. The analysis methodologies considered have been compared, in order to evaluate the effectiveness of the simplest VI technique to predict the seismic damage and vulnerability of the investigated structures.

\section{THE MUNICIPALITY OF ARSITA: DATA AND POST-EARTHQUAKE RECONSTRUCTION PLAN}

Arsita (Figure 1) is a town with 889 inhabitants, located in the district of Teramo (the Abruzzo region of Italy) at about $470 \mathrm{~m}$ above sea level. It is placed in the upper valley of the Fino river, near the Gran Sasso massif. Arsita is part of the mountain community of Vomano, Fino, and Piomba and it is also located within the Laga Mountains National Park. The municipal territory extends over about $30 \mathrm{~km}^{2}$ and, therefore, the population density is about 30 inhabitants per $\mathrm{km}^{2}$. The historic center and the four isolated hamlets of Bivio Arsita, Colle dei Cerri, Colle Mesole and Pantane are part of the municipality of Arsita, where pre-Roman remains from the eighth century B.C., and Roman coins, floors of buildings and small statues of the early Christian era are found.

Called Bacucco until 1905, Arsita emerged in the later Middle Ages around a fortified castle called Castello Bacucco, which originally belonged to the Count of Chieti, then to the monks of Montecassino and finally to the Casa d'Este. The village was sold in 1583 to Margaret of Austria Farnese. Other historians claim that Bacucco took its name from the Roman word for the God Bacchus. 


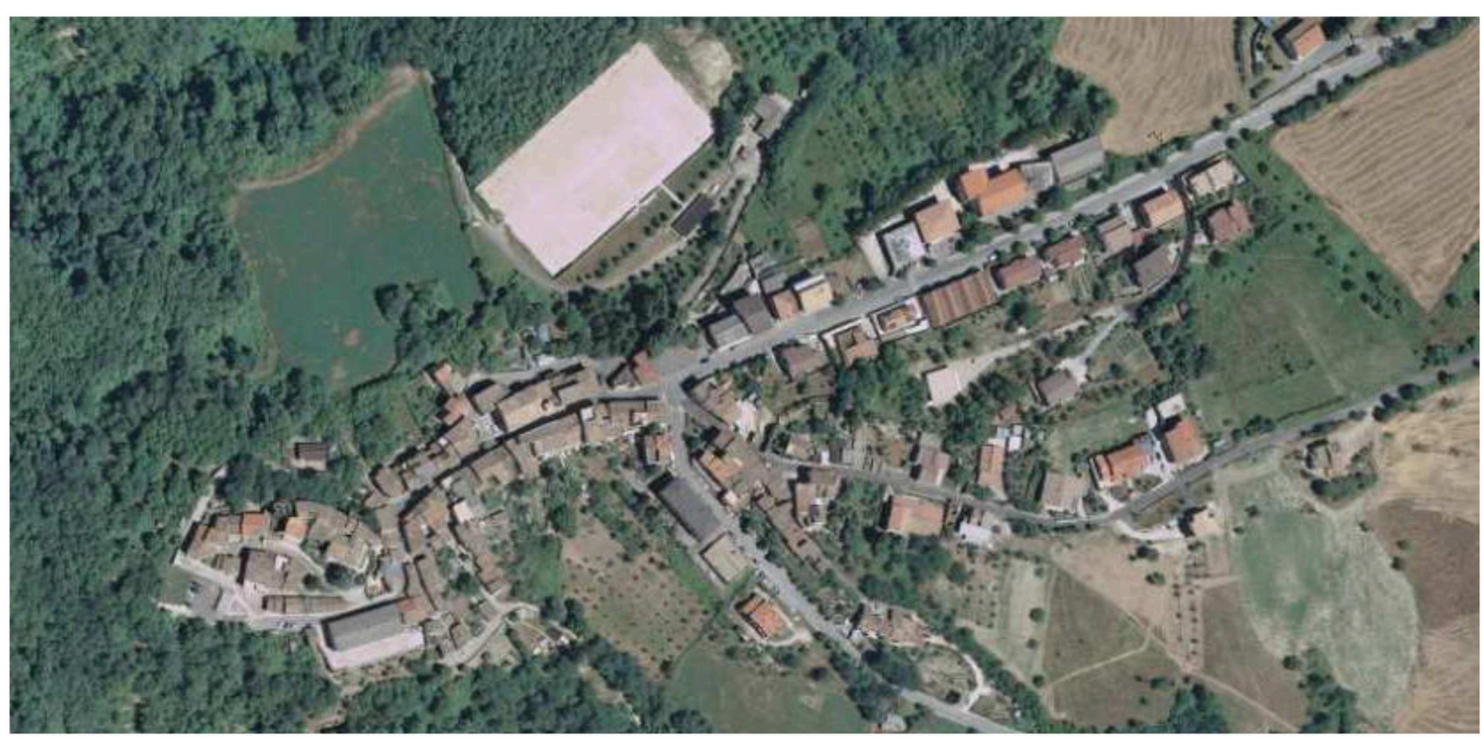

FIGURE 1 | Birds-eye view of the municipality of Arsita (source: Google maps).

In the twelfth century the town was owned by the ruling Acquaviva family. Its current urban configuration can be traced back to the late Middle Ages-early Renaissance. In 1806, the town came under the rule of the town of Penne. During the Napoleonic period a good number of brigands held the territory in and around Arsita. A series of skirmishes occurred during this period. In the early nineteenth century the waters from a spring in this area were said to have healing powers. Nowadays, Arsita founds its richness on agriculture, sheep-farming and local craft activities. On the night of April 6th 2009 the municipality was affected by an earthquake of magnitude $\left(\mathrm{M}_{\mathrm{w}}\right) 6.3$, which hit a very large area of the Abruzzo region with an epicenter at low focal depth $(9.5 \mathrm{~km}$, coordinates $42,348 \mathrm{~N}, 13,380 \mathrm{E})$ very close to the city of L'Aquila (about $7 \mathrm{~km} \mathrm{SO}$ ). This main event was the strongest of a sequence initiated a few months earlier, consisting of 23 seismic shocks of magnitude 4 between March 30th and April 23rd and two significant aftershocks $\left(\mathrm{M}_{\mathrm{W}} 5.6\right.$ on April 7th and $\mathrm{M}_{\mathrm{W}} 5.4$ on April 9th). The consequences of this seismic sequence were very serious, with 18,000 damaged buildings, 305 casualties, about 1,500 injured and 70,000-80,000 residents temporarily evacuated in the first months after the disaster.

About 2 years after the L'Aquila seismic sequence, a scientific team set up by ENEA (Italian National Agency for New Technologies, Energy and Sustainable Economic Development), with the Universities of Pescara-Chieti “G. D’Annunzio," Naples "Federico II" and Ferrara, were tasked with a post-earthquake reconstruction plan for the Municipality of Arsita, whose contents can be found at a dedicated website (http://www.pdrarsita.bologna.enea.it/).

The small and nice historic center of Arsita presents a very inhomogeneous built heritage with regards to earthquake damage, vulnerability, past interventions, maintenance, and signs of past seismic events. The ancient nucleus consisted of a fortified construction (a masonry tower now in ruins), due to its strategic importance in the territory, providing for its present wonderful position in the landscape. Furthermore, the historic center is enshrined with notable palaces and churches (Figures 2A,B). Other than these important cultural heritage sights, the historical center includes a series of articulated building compounds typical of the Abruzzo region (Figure 2C).

Although the Intensity level (VI MCS) of the L'Aquila earthquake which affected Arsita was considered moderate, the combination of several factors (mainly high potential vulnerability, particular topographic and soil conditions) led to non-negligible widespread damage. Therefore, first, the Arsita Technical Office defined that the building clusters (depending on their structural continuity) needed to be either repaired or rehabilitated. Thus, the investigation of the historical center was focused on the effectiveness of a multidisciplinary approach based on the simultaneous application of Remote Sensing techniques, GIS (Geographical Information System) tools, DGPS and Laser Scanner surveys. In particular, the data acquisition was based first on direct visual surveys of the external and internal parts of all concerned constructions, including the measurement of the main geometric characteristics and the assessment of structural parts (walls, floors, roofs, etc.), materials, construction details and techniques. Samples of the most important materials (stone, brick, mortar, etc.) were collected, with the aim to perform characterization laboratory tests.

At the same time, the (AeDES, 2000), filled in by the Civil Protection expert teams during the emergency phase for the evaluation of seismic damage and safety, were studied, verified and digitized. Moreover, urban planning, architectonic, and energetic forms were also filled in order to investigate building descriptions and energetic aspects. 

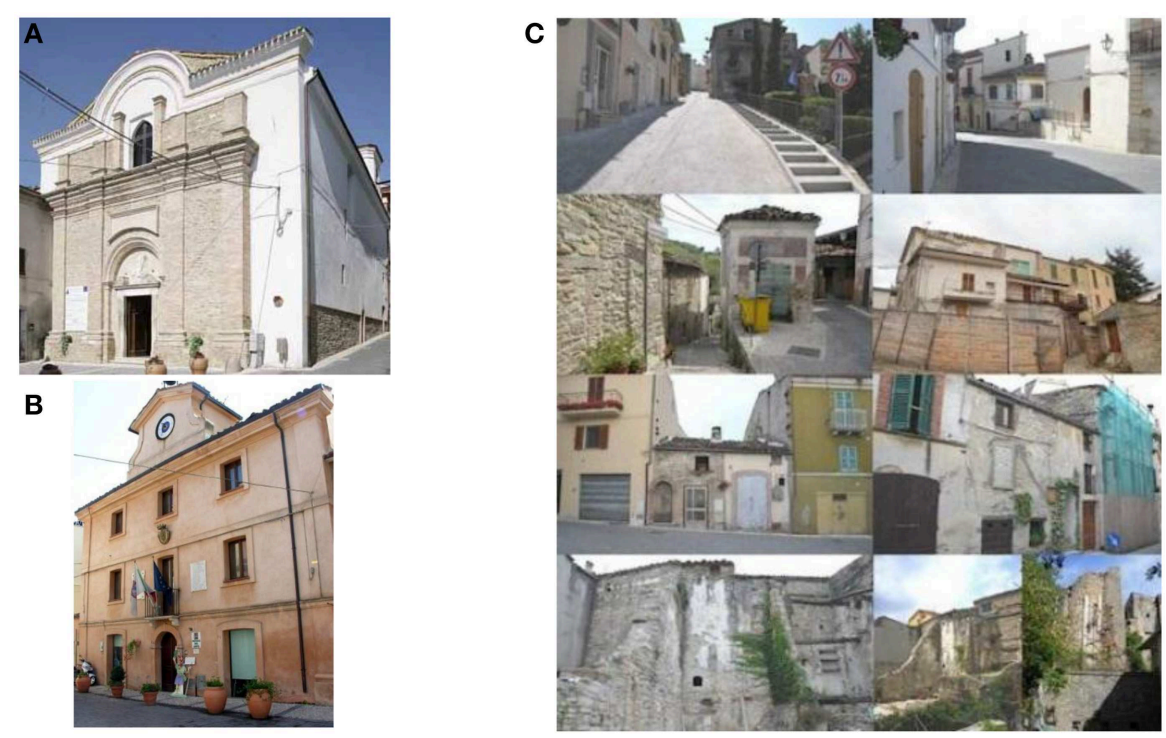

FIGURE 2 | Cultural and residential heritages of the historical center of Arsita: Santa Vittoria church (A), Wolf Museum (B), and some clustered buildings (C) (source: personal archive).

After this phase, some quick and more refined procedures for vulnerability evaluation, namely Famive (D'Ayala and Speranza, 2002), GNDT (1993), a vulnerability assessment form purposely conceived for masonry clusters (Formisano et al., 2011, 2015) and MEDEA (Papa and Zuccaro, 2004), were applied to the structural units of examined masonry clusters in order to have a clear picture of their weak points from a seismic perspective. This activity was very important to define precise guidelines for the rehabilitation of the structural typologies of clustered buildings within these historical centers.

\section{SELECTION AND MAIN PROPERTIES OF THE CLUSTERED BUILDINGS UNDER STUDY}

In the framework of the post-earthquake reconstruction plan of Arsita in-situ investigations were performed in order to subdivide the historical center of masonry clusters, in which appropriate seismic vulnerability analyses and retrofitting interventions were executed on. Therefore, 17 masonry clusters, made up of a total of 91 structural units, were individuated (Figure 3A).

The case study herein considered is a masonry cluster identified as number 8 and composed of four structural units (S.U.) named 8A, 8B, 8C, and 8D (Figure 3B).

The building aggregate, erected earlier than 1919, is characterized by a discrete architectural value and has both residential and productive uses. The constitutive materials are masonry stones typical of the Abruzzo region. Horizontal structures are made of steel beams and hollow slab blocks. Timber beams, which sustain overlying timber planks and tiles, are the load-bearing members of roofing. Regarding the morphology, the cluster is rather regular in plan, while the major discontinuities are detected in elevation, with the presence of staggered floors and floors at different heights due to the soil slope. Plan layouts, vertical sections and external views of the inspected clustered buildings are shown in Figures 4-6, respectively.

In this study the intermediate (8B) and head (8C) structural units, characterized by different structural behaviors deriving from the dissimilar geometric conformations and in-plane location, are examined in detail.

\section{MACROELEMENT MODELING AND PUSHOVER ANALYSIS}

Macro-element models of both the whole building cluster and single S.U. have been implemented by means of the 3Muri calculation software (Lagomarsino et al., 2013; STA DATA srl., 2018).

Through the guidelines delivered by the Italian Ministry of Cultural Heritage and Activities (Ministry of Cultural Heritage and Activities (MiBAC), 2011) concerning the assessment, prevention, and mitigation of the seismic risk, it has been possible to identify the constructive type of the investigated cluster, useful for modeling issues in the 3Muri program. In this calculation software the so-called macro-elements method is used. This modeling technique sees masonry walls as an assemblage of masonry piers, spandrels and rigid nodal panels. The masonry walls are then transformed into equivalent frames aiming at running pushover analyses. To this purpose, initially, all the geometric and mechanical information on the structures under study have been collected. Plan layouts of the S.U. in dxf format have been imported into the program and, after the walls, floors, and roofs have been modeled, mechanical features of materials have been assigned to the structural components on the basis of the standard provisions in the case of LC1 knowledge level, since 
A

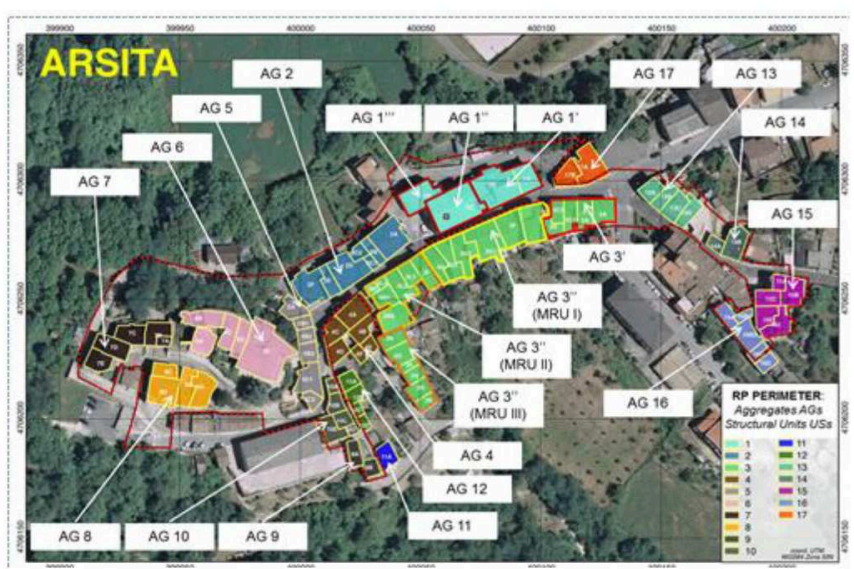

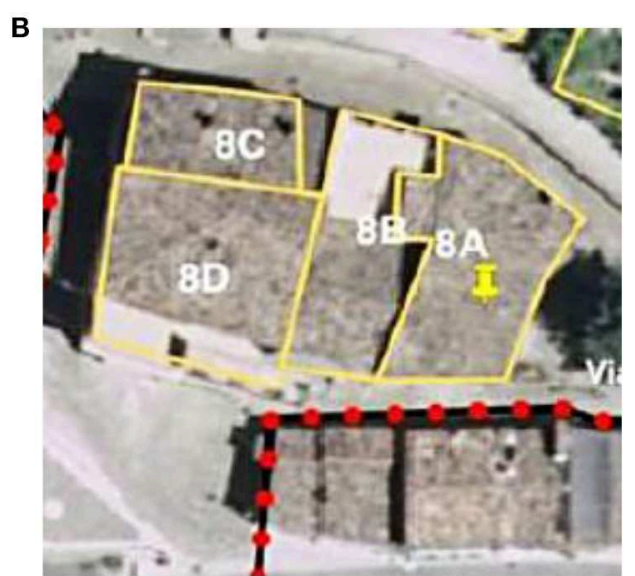

FIGURE 3 | Masonry compounds of the historical center of Arsita (A) and the clustered buildings under study (B) (source: http://www.pdr-arsita.bologna.enea.it/).
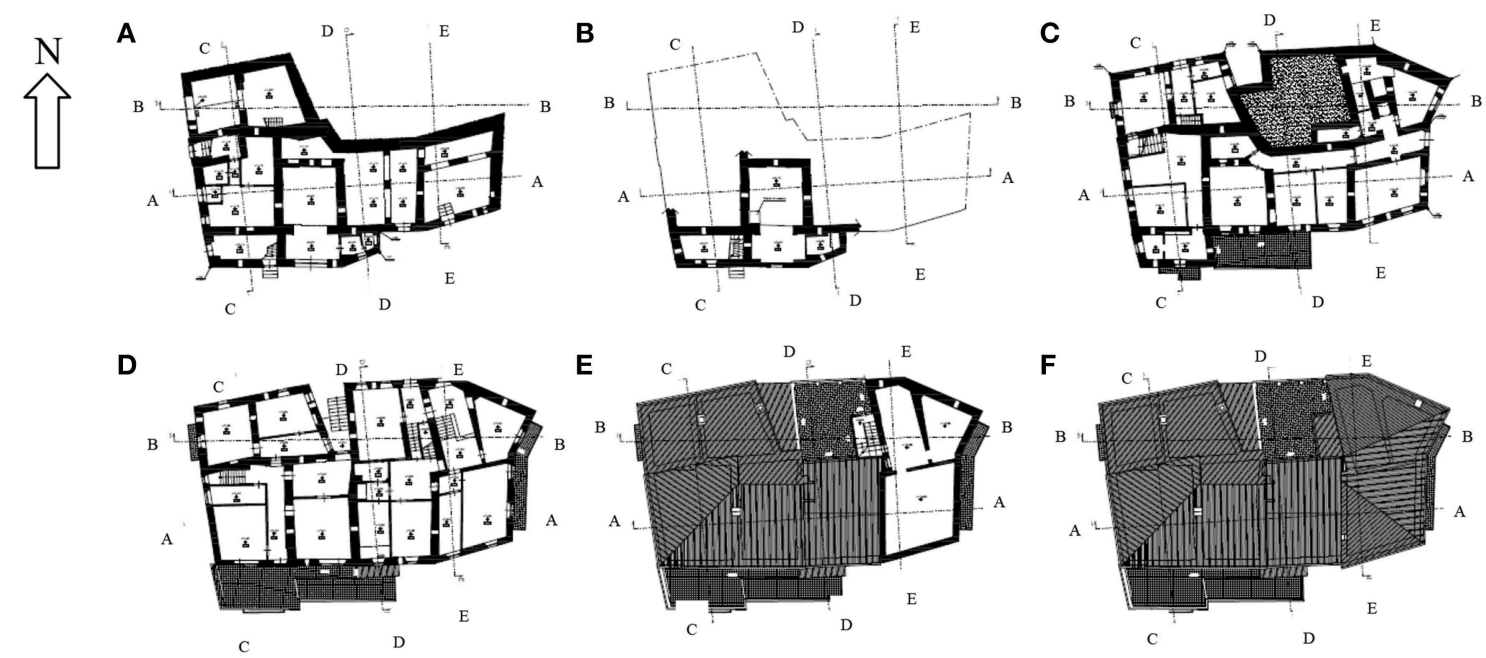

FIGURE 4 | Plan layouts of the building cluster under study: ground (A), mezzanine (B), first (C), second (D), attic (E), and roof floors (F).

in this case no destructive and non-destructive tests on materials have been performed. Subsequently, the loads applied to floors and roofs have been assigned and the presence of staircases, due to the impossibility of the program to proceed with their explicit modeling, has been taken into account, applying the dead weight and relative loads to the supporting masonry walls.

Therefore, based on the above modeling approach, the macroelement models of both the whole buildings cluster (Figure 7A) and the S.U. 8B and 8C have been set up (Figures 7B,C).

In particular, it has been chosen to inspect in detail head and intermediate S.U. in order to show their different seismic behaviors due to the dissimilar in-plane positions they have in the compound of constructions. All of the above macro-element models have been analyzed by pushover analysis, which is the most common method proposed by the current standard for non-linear seismic analysis of existing structures. The method consists of applying some distributions of gradually increasing forces to the structure, to attain the local or global collapse. In this way the damaging effect of the earthquake is known, starting from the MDOF structure capacity curve, which is then transformed into the bi-linear curve representative of the SDOF equivalent system.

Non-linear static analyses have been carried out, considering the units both individually and within the cluster, in order to compare their seismic behavior in terms of base sheardisplacement curves on the basis of a simple vulnerability index.

First, from the analysis carried out using the 3Muri software, the MDOF pushover curves of isolated S.U. have been plotted in directions $\mathrm{X}$ and $\mathrm{Y}$ together with the main damage states detected for increasing displacement levels up to the collapse (Figures 8-11).

From the analysis results it appears that S.U. B and C suffered plastic and failure states due to compression-bending mechanisms being more than shear in both analysis directions. 

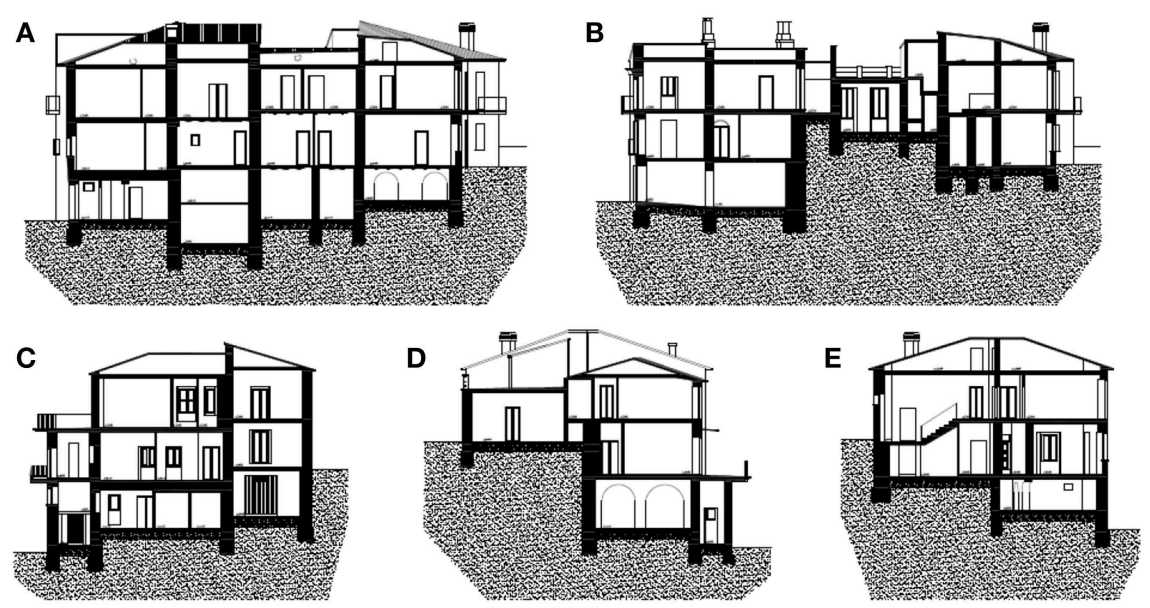

FIGURE 5 | Vertical sections of the building cluster under study: A-A (A), B-B (B), C-C (C), D-D (D), and E-E (E).
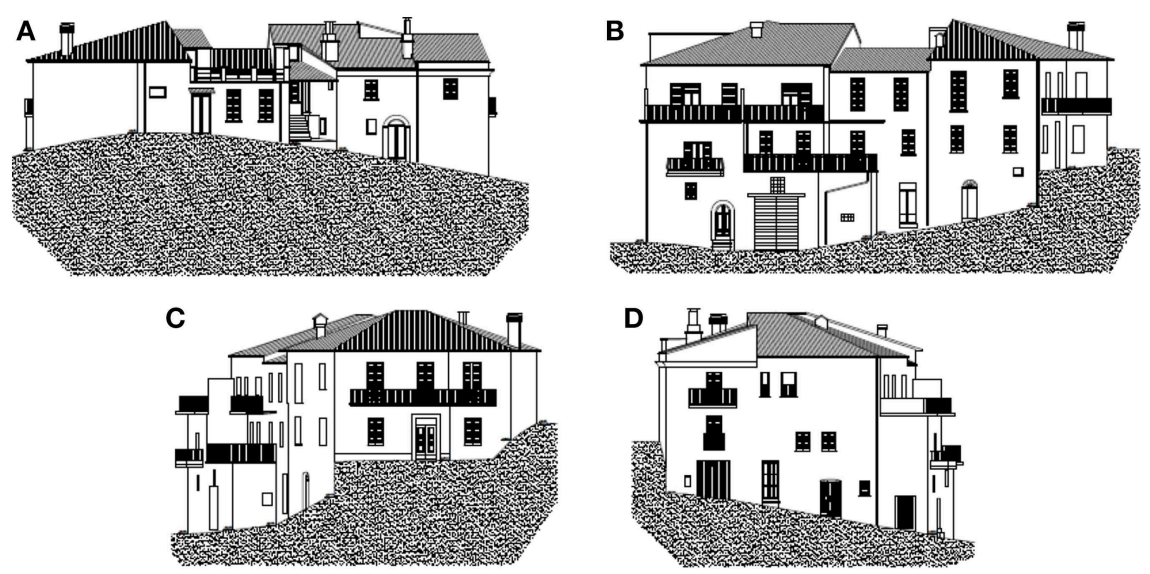

FIGURE 6 | External views of the building cluster under study: north (A), south (B), east (C), and west (D).

A

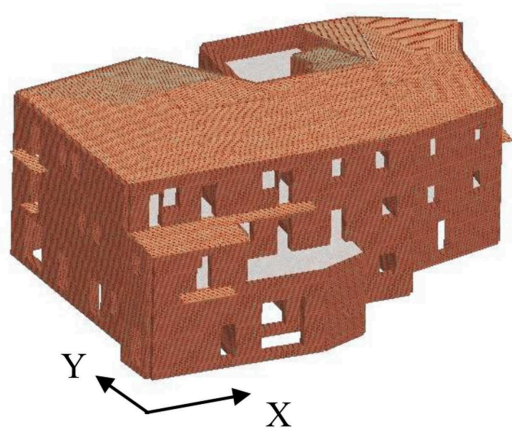

B

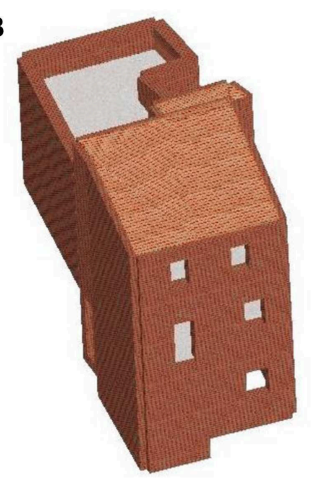

C

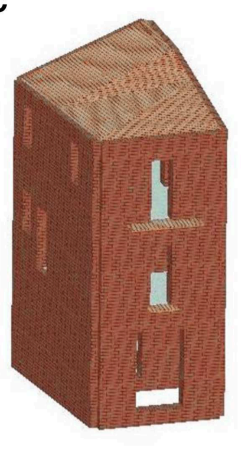

FIGURE 7 | Macro-element modeling: the whole cluster (A) and S.U. 8B (B) and 8C (C). 
A

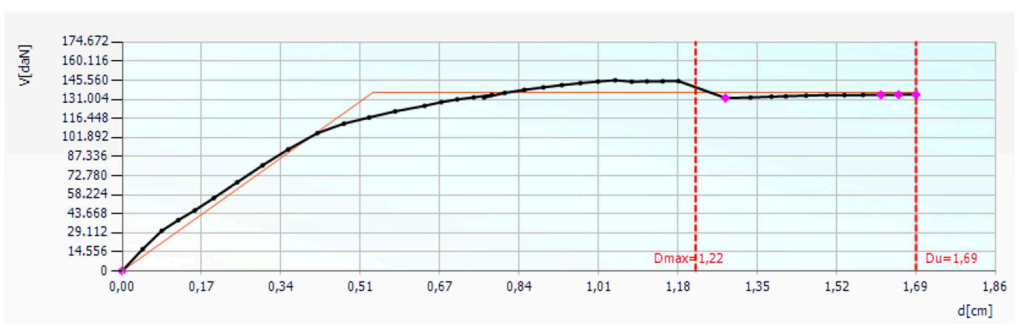

\begin{tabular}{|l}
$\square$ No damage \\
$\square$ Shear - plastic \\
$\square$ Shear - failure \\
$\square$ Compression-bending - plastic \\
$\square$ Compression-bending - failure \\
$\square$ Elastic failure
\end{tabular}

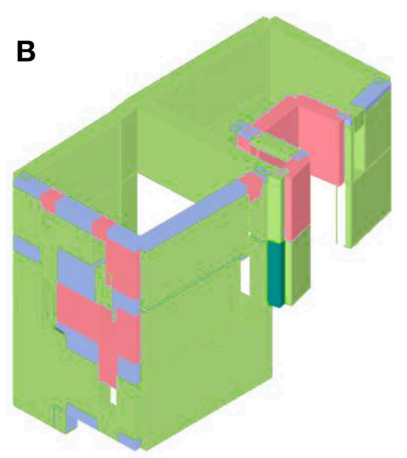

D

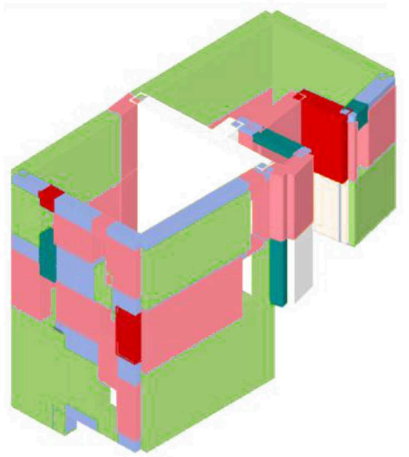

FIGURE 8 | Seismic behavior in direction X of the isolated S.U. type B: MDOF pushover curve (A) and damage patterns related to the conventional yielding limit (B), maximum base shear (C), and ultimate displacement $D_{u}$ (D).

A

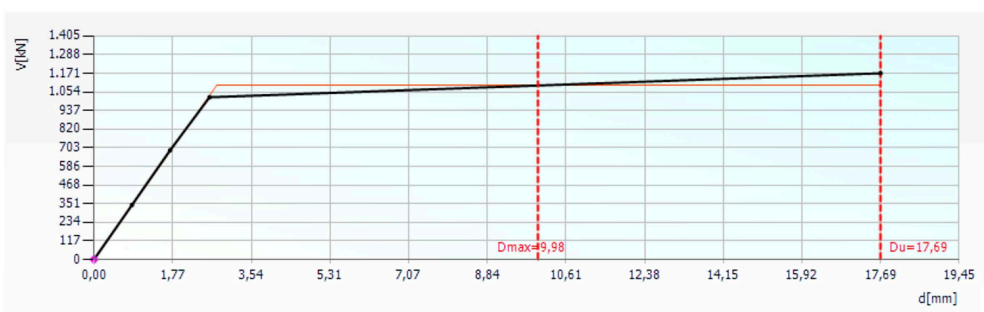

B

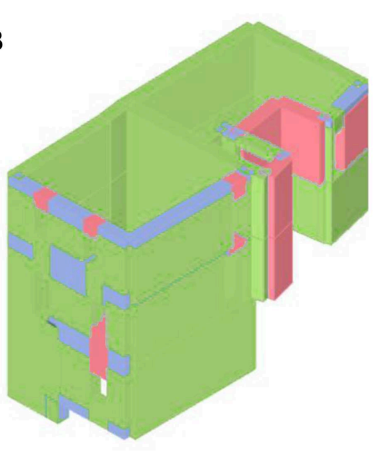

C

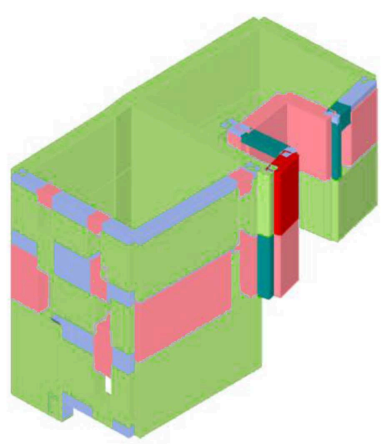

FIGURE 9 | Seismic behavior in direction Y of the isolated S.U. type B: MDOF pushover curve (A) and damage patterns related to the conventional yielding limit (B) and ultimate displacement $\mathrm{D}_{\mathrm{u}} \mathbf{( C )}$. 


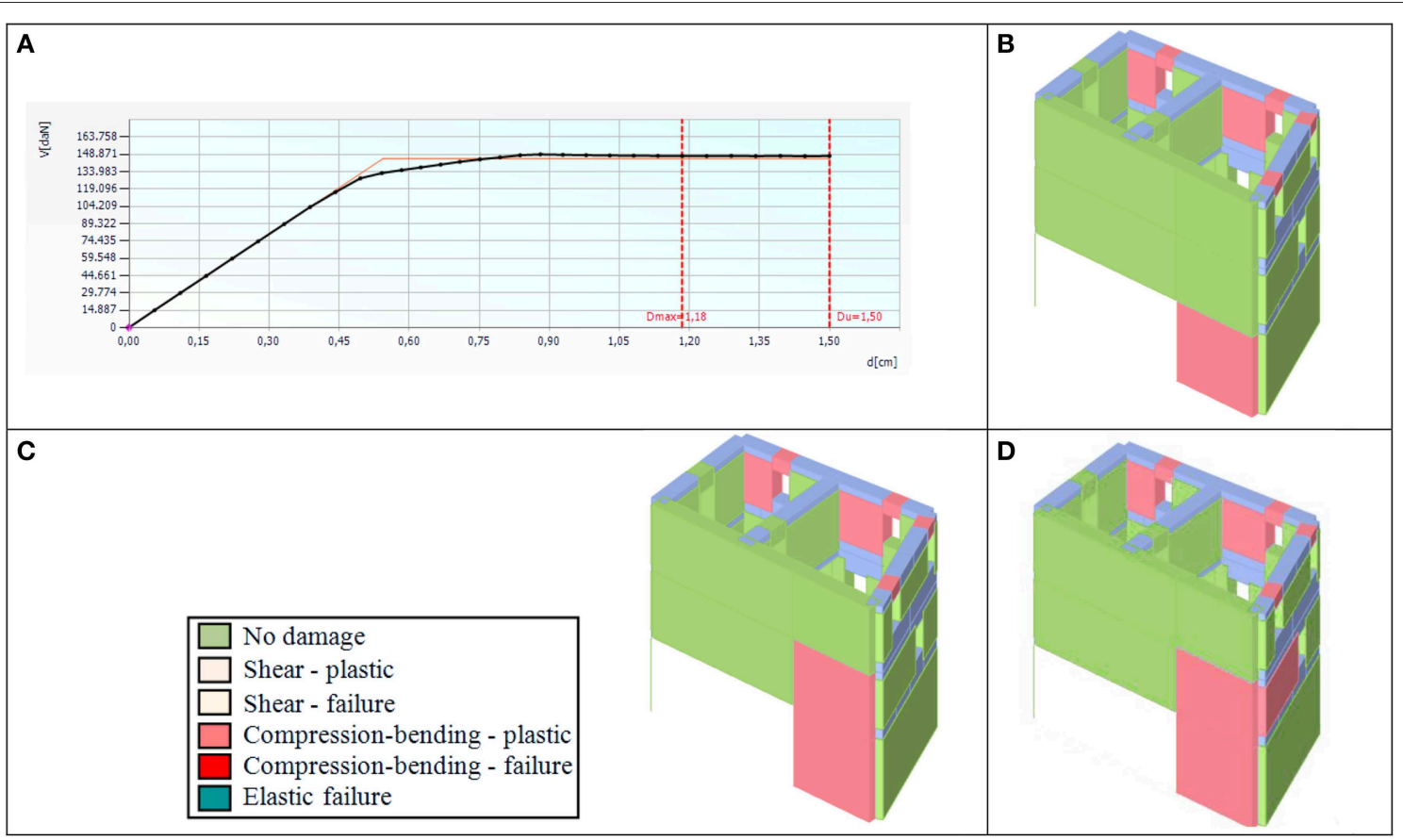

FIGURE 10 | Seismic behavior in direction X of the isolated S.U. type C: MDOF pushover curve (A) and damage patterns related to the conventional yielding limit (B), maximum base shear (C), and ultimate displacement $D_{u}(\mathbf{D})$.

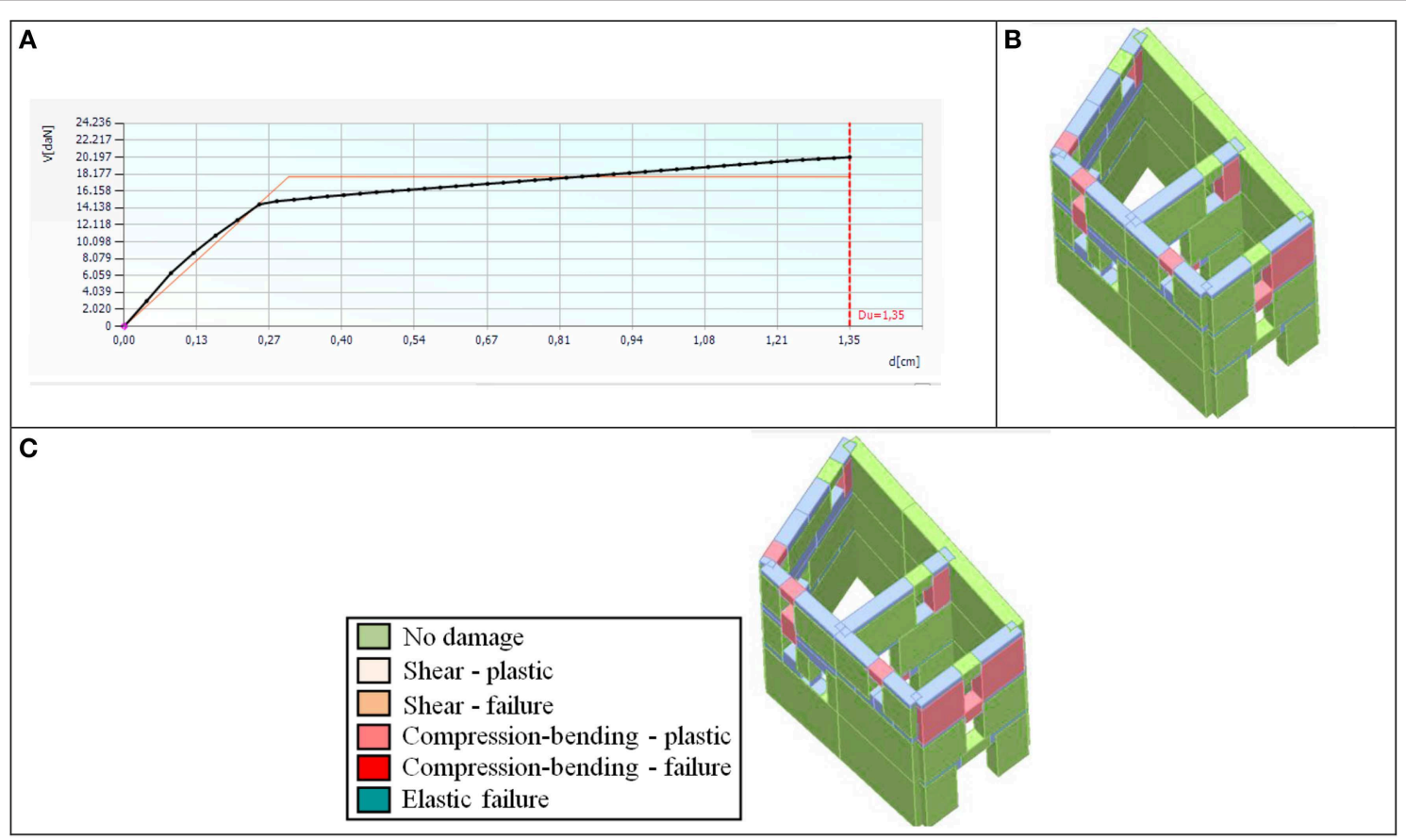

FIGURE 11 | Seismic behavior in direction Y of the isolated S.U. type C: MDOF pushover curve (A) and damage patterns related to the conventional yielding limit (B) and ultimate displacement $\mathrm{D}_{\mathrm{u}}$ (C).

Subsequently, it has been possible, through the theory of the equivalence of areas, to pass from the MDOF curves to the SDOF bi-linear curves of S.U. 8B and 8C.
On the other hand, the curves of these S.U. have been directly obtained from the analysis results on the global cluster by considering their interaction with other units 
in calculating the base shear and in estimating the top displacement. In particular, for a given analysis direction and for each loading step, the base shear has been calculated as the algebraic sum of all shears of masonry walls in that direction, taking into account the loads deriving from adjacent S.U., while the top displacement has been determined as the average value among displacements of all nodes of the last story.

So, in both cases (isolated structures and clustered ones), the maximum displacements required by the earthquake $\left(D_{\max }\right)$ have been estimated and, consequently, the related vulnerability indices have been computed. The bi-linear curves of single S.U and clustered ones in directions $\mathrm{X}$ and $\mathrm{Y}$, together with the comparisons in terms of vulnerability indices, have been reported for S.U. 8B and 8C in Figure 12.
From the results collected, it is clear that the structural units in cluster conditions have, in all cases, vulnerability indices lower than those achieved when they are considered as isolated buildings. This effect is more clearly marked in direction X. for S.U. 8C, which has a vulnerability index lower than the one attained in direction Y. On the contrary however, for S.U. 8B vulnerability indices in both analysis directions are comparable to each other.

\section{QUICK SEISMIC VULNERABILITY ASSESSMENT}

An additional seismic evaluation methodology has herein been used to evaluate, through a simple vulnerability
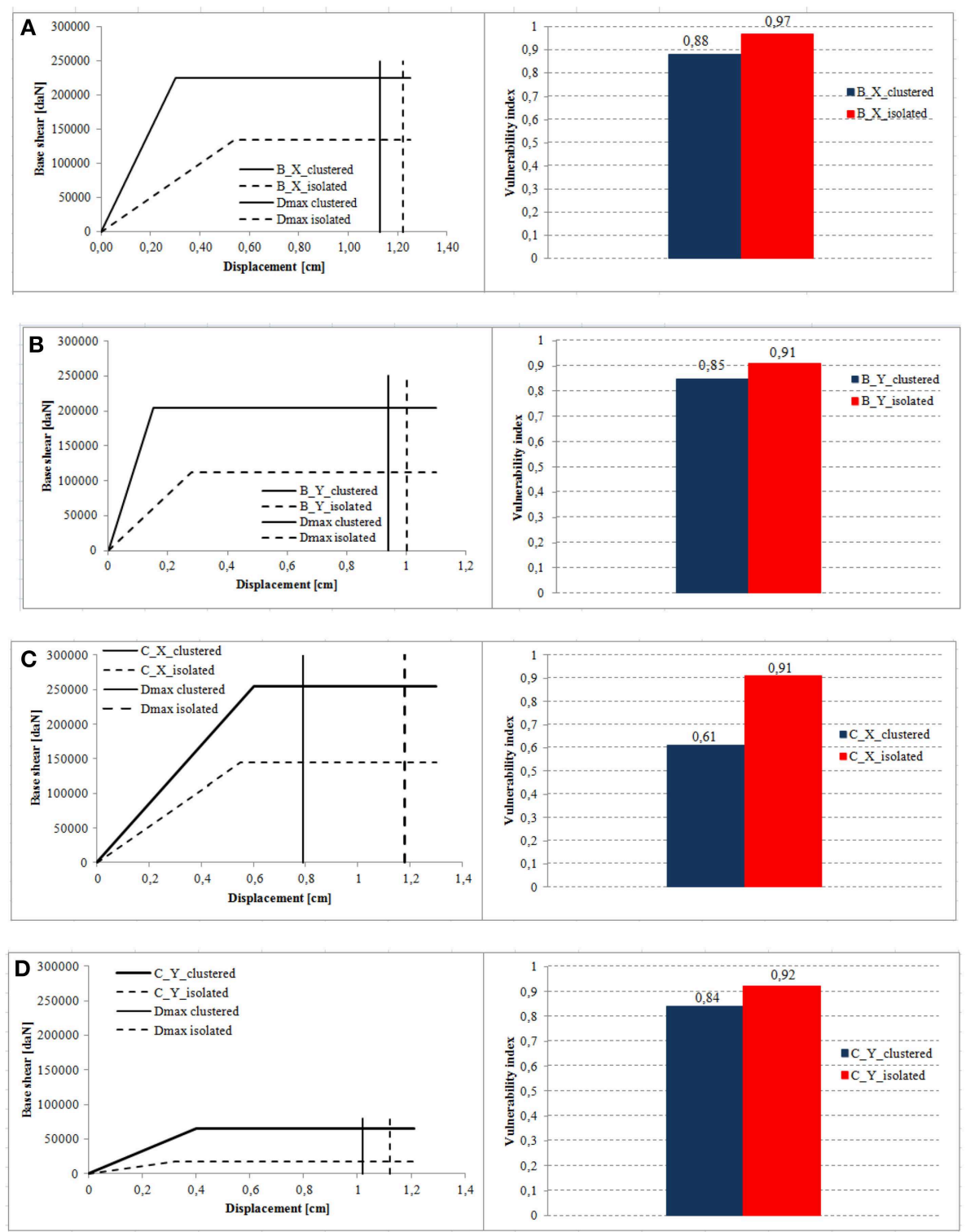

FIGURE 12 | Pushover curves and comparison in terms of vulnerability indices for S.U. 8B in directions $X$ (A) and $Y$ (B) and for S.U. 8C in directions $X$ (C) and $Y$ (D). 
TABLE 1 | Quick form based vulnerability index of the S.U. type B.

Cluster $\mathbf{N}^{\circ} 8$ Building B

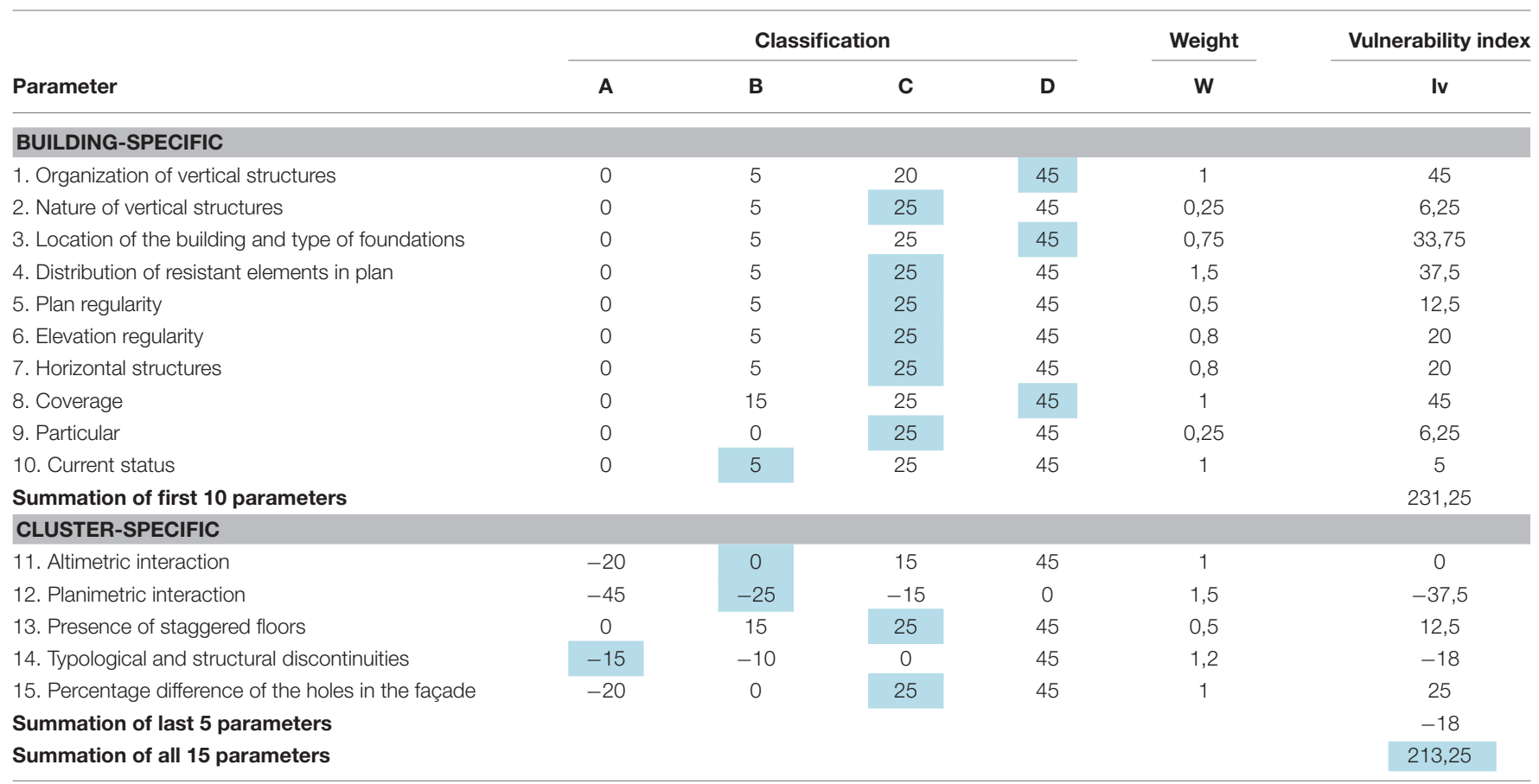

For each structural unit the colored values are the classes attributed to the parameters.

form appropriately conceived for S.U. of masonry clusters, the seismic behavior of the inspected masonry building compound no.8.

The applied procedure is based on the (Benedetti and Petrini, 1984), elaborated about 35 years ago to estimate the seismic vulnerability of single constructions using 10 buildingspecific parameters. The 10 parameters are representative of the buildings structural behavior, they concern the organization and nature of vertical structures, the location of the building and type of foundations, the distribution of seismic-resistant elements, the in-plan and in-elevation irregularities, the type of floors and roofs, the structural details and the maintenance state. For each of the 10 parameters a class score, from $\mathrm{A}$, the best, to $\mathrm{D}$, the worst, is assigned. In addition, a weight is provided for each parameter. The weights take into account the minor or major importance that the various parameters have on the seismic behavior of the structure. They are characterized by a number varying from 0.25 to 1.50 . Scores and weights were determined through the statistical analysis of damage data collected during recent earthquakes. Therefore, the vulnerability index is defined as the sum of the class score of each parameter multiplied by the respective weight. This index is then normalized into a range [0-1], where 0 indicates buildings complying with current seismic regulations, while 1 is representative of buildings with poor seismic behavior.

Starting from this study and according to recent research (Formisano et al., 2015, 2017b), five new cluster-specific parameters (in-plane and in-elevation interactions, staggered floors, typological and structural discontinuities, and difference of opening areas among adjacent facades) have been added to the original form in order to consider the interactions among S.U. when grouped in clusters. It is worth noting that the class scores of some of the new parameters assume negative values when they reduce the seismic vulnerability. Therefore, the final result is a modified form with 15 parameters capable of estimating, in quick and simple way, the seismic vulnerability of S.U. in historical centers. As in the original form, in the extended form the vulnerability index can be normalized in the range [0-1].

The vulnerability form for masonry cluster buildings has been filled in for S.U. $8 \mathrm{~B}$ and $8 \mathrm{C}$, providing the results illustrated, respectively, in Tables 1, 2, where it is evident that the investigated buildings have an almost equal vulnerability index.

Finally, in Figure 13 the comparison between vulnerability indices derived from 3 Muri analyses and the simplified form ones are made.

From this comparison it has been shown that:

- The macro-element method provides indices higher than those of the vulnerability form. However, the two methods can be compared to each other only in qualitative terms, since the parameters considered for seismic vulnerability assessment (qualitative judgements in case of the form and quantitatively measured displacements in case of the macroelement analysis) are different.

- Structural units 8B and 8C have similar seismic vulnerability indices in both analysis directions. This is achieved using both analysis methods. 
TABLE 2 | Quick form based vulnerability index of the S.U. type C.

Cluster $\mathbf{N}^{\circ} 8$ Building $\mathrm{C}$

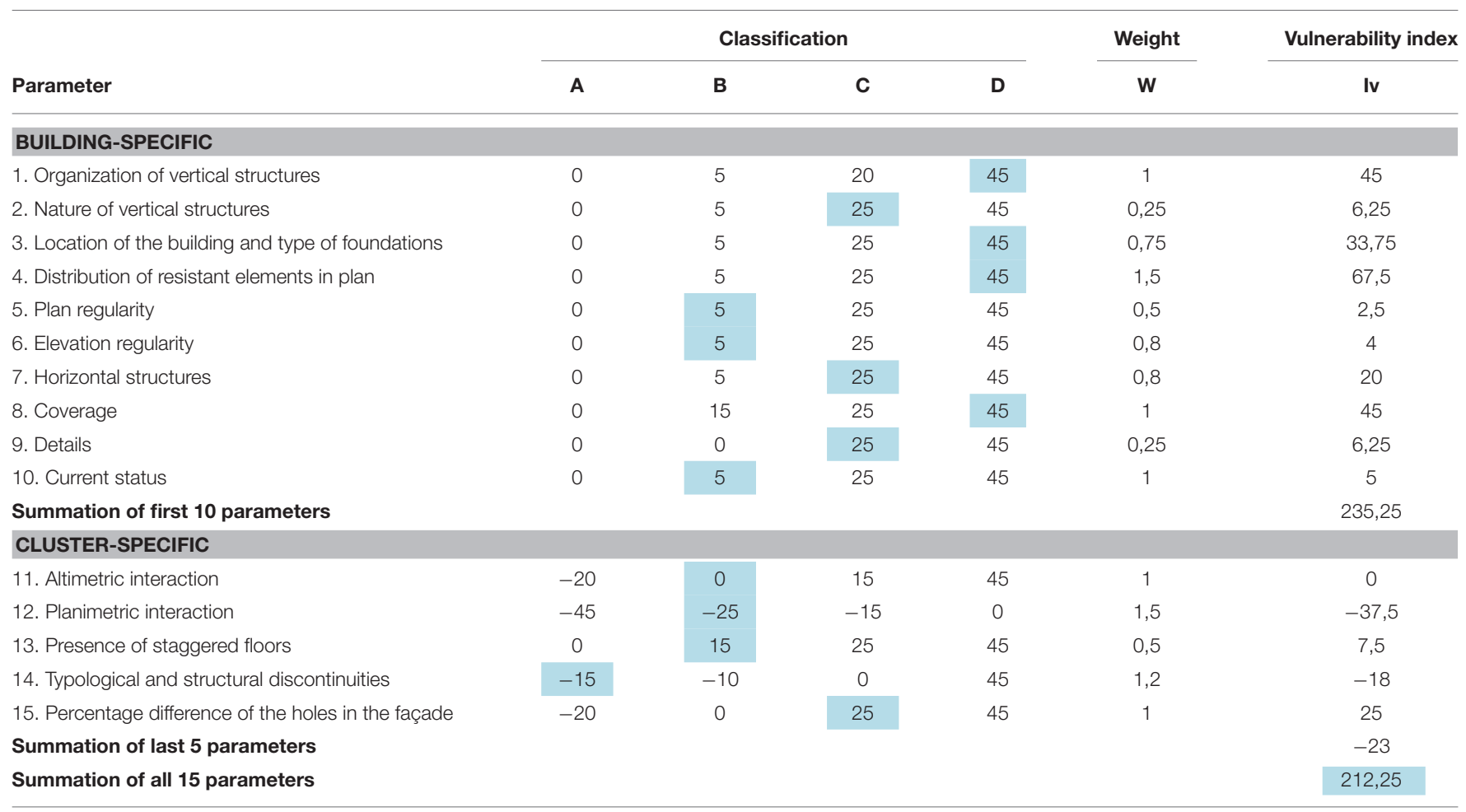

For each structural unit the colored values are the classes attributed to the parameters.

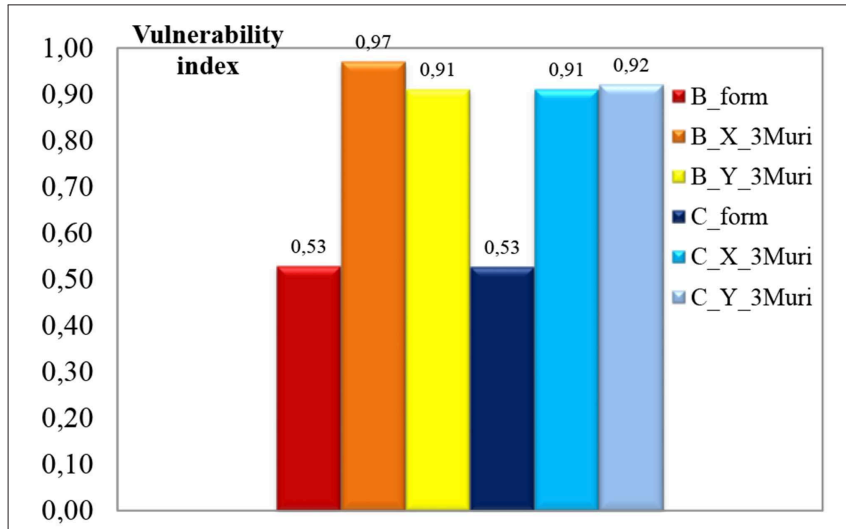

FIGURE 13 | Comparison of vulnerability indices.

- The simple and quick vulnerability assessment method is then able to predict, in relative terms, the same results of more refined analyses. In fact, the spirit of application of the simplest method is not to quantitatively evaluate the vulnerability indices of the two investigated S.U., but to compare their seismic indicators in a relative way, in order to evaluate what is the most vulnerable S.U. In the case under study, the two form vulnerability indices are equal, confirming that the two S.U. have the same seismic vulnerability. The same result is achieved for numerical analyses, where the vulnerability indices of two S.U. in both analysis directions are basically the same. This confirms the reliability of the quick survey form in predicting the seismic vulnerability of structural units of masonry building clusters.

\section{CONCLUSIONS}

In the current paper the seismic vulnerability of a masonry building compound in the historical center of Arsita (district of Teramo) damaged by the 2009 L'Aquila earthquake was assessed. Two structural units placed in intermediate and head positions were investigated by means of two analysis methods. The first method was based on pushover analysis results obtained on the basis of macro-element models, implemented through the 3Muri analysis program, of the two buildings both considered as isolated structures and within the construction compound. The second method was instead founded on a simple and quick vulnerability form appropriately conceived for structural units of masonry building clusters.

The comparison of results derived from numerical modeling showed that buildings considered as isolated structures have a strength and stiffness lower than those of the same structures grouped in aggregate. Moreover, from the comparison, in terms of vulnerability indices, it was found that the cluster condition 
reduces the seismic vulnerability of both structural units and that this effect is more marked for S.U. 8C in direction X.

On the other hand, the comparison of results derived from filling the vulnerability form in for the two buildings provided almost equal indices.

Finally, macro-element indices were compared to vulnerability form indices. The comparison showed that structural units $8 \mathrm{~B}$ and $8 \mathrm{C}$ have similar seismic vulnerability indices in both analysis directions, independent of the analysis method used. Therefore, as a conclusion, the vulnerability assessment form method was able to predict, in relative terms, the same results of more refined analyses. This confirmed the effectiveness of the survey form for cluster structural units to estimate, in a simple and rapid

\section{REFERENCES}

AeDES (2000). First Level Form for Safety Assessment, Damage Investigation, Prompt Intervention for Ordinary Buildings in the Post-Earthquake Emergency (in Italian). Rome: Civil Defense Department.

ATC (1996). Seismic Evaluation and Retrofit of Concrete Buildings. ATC-40 Report, Redwood City, CA: Applied Technology Council.

Benedetti, D., and Petrini, V. (1984). On the seismic vulnerability of masonry buildings: proposal of an evaluation method (in Italian). L'Industria delle Costruzioni. 149, 66-74.

Bernardini, A. (2000). The Vulnerability of Buildings: Evaluation at National Scale of Seismic Vulnerability of Ordinary Buildings (in Italian). Research Report, Rome: CNR-National Group for Defence against Earthquakes.

Bernardini, A., Gori, R., and Modena, C. (1990). “An application of coupled analytical models and experiential knowledge for seismic vulnerability analyses of masonry buildings," in Engineering Aspects of Earthquake Phenomena, Vol. 3, eds A. Koridze (Oxon: Omega Scientific), 161-180.

Brando, G., De Matteis, G., and Spacone, E. (2017). Predictive model for the seismic vulnerability assessment of small historic centres: application to the inner Abruzzi Region in Italy. Eng. Struct. 153, 81-96. doi: 10.1016/j.engstruct.2017.10.013

Calvi, G. M., Pinho, R., Magenes, G., Bommer, J. J., Restrepo-Vélez, L. F., and Crowley, H. (2006). Development of seismic vulnerability assessment methodologies over the past 30 years. ISET J. Earthquake Technol. 43, 75-104.

Caprili, S., Mangini, F., Salvatore, W., Bevilacqua, M. G., Karwacka Codini, E., Squeglia, N., et al. (2017). A knowledge-based approach for the structural assessment of cultural heritage, a case study: La Sapienza Palace in Pisa. Bull. Earthquake Eng. 15, 4851-4886. doi: 10.1007/s10518-0170158-y

Cara, S., Aprile, A., Pelà, L., and Roca, P. (2018). Seismic risk assessment and mitigation at emergency limit condition of historical buildings along strategic urban roadways. Application to the "Antiga Esquerra de L'Eixample" neighborhood of Barcelona. Int. J. Arch. Heritage 12, 1055-1075. doi: 10.1080/15583058.2018.1503376

Chieffo, N., Mosoarca, M., Formisano, A., and Apostol, I. (2019). "Seismic vulnerability assessment and loss estimation of an urban district of Timisoara," in IOP Conference Series: Materials Science and Engineering (Prague), 471.

Clementi, F., Gazzani, V., Poiani, M., and Lenci, S. (2016). Assessment of seismic behaviour of 490 heritage masonry buildings using numerical modelling. J. Build. Eng. 8, 29-47. doi: 10.1016/j.jobe.2016.09.005

Da Porto, F., Munari, M., Prota, A., and Modena, C. (2013). Analysis and repair of clustered buildings: case study of a block in the historic city centre of L'Aquila (Central Italy). Construct. Build. Mater. 38, 1221-1237. doi: 10.1016/j.conbuildmat.2012.09.108

D'Amato, M., Laterza, M., and Diaz Fuentes, D. (2018). Simplified seismic analyses of ancient churches in Matera's landscape. Int. J. Arch. Heritage. doi: 10.1080/15583058.2018.1511000. [Epub a head of print]. way, the seismic vulnerability of buildings within Italian historical centers.

\section{DATA AVAILABILITY}

The datasets generated for this study are available on request to the corresponding author.

\section{AUTHOR CONTRIBUTIONS}

GC performed numerical analyses and filled the vulnerability forms. AF conceived the analysis methodology and wrote the paper.

D'Ayala, D., and Paganoni, S. (2011). Assessment and analysis of damage in L'Aquila historic city centre after 6th April 2009. Bull. Earthquake Eng. 9, 81-104. doi: 10.1007/s10518-010-9224-4

D’Ayala, D., and Speranza, E. (2002). “An integrated procedure for the assessment of seismic vulnerability of historic buildings," in Proceedings of the 12th European Conference on Earthquake Engineering (London).

Formisano, A. (2017a). Local- and global-scale seismic analyses of historical masonry compounds in San Pio delle Camere (L'Aquila, Italy). Nat. Hazards 86, 465-487. doi: 10.1007/s11069-016-2694-1

Formisano, A. (2017b). Theoretical and numerical seismic analysis of masonry building aggregates: case studies in San Pio Delle Camere (L'Aquila, Italy). J. Earthquake Eng. 21, 227-245. doi: 10.1080/13632469.2016.1172376

Formisano, A., Chieffo, N., Monaco, D., and Fabbrocino, F. (2016). "On the influence of the aggregate condition on the vibration period of masonry buildings: a case study in the district of Naples," in AIP Conference Proceedings (Athens), 1790.

Formisano, A., Chieffo, N., and Mosoarca, M. (2017a). Seismic vulnerability and damage speedy estimation of an urban sector within the municipality of San Potito Sannitico (Caserta, Italy). Open Civ. Eng. J. 11, 1106-1121. doi: 10.2174/1874149501711011106

Formisano, A., Chiumiento, G., Fabbrocino, F., and Landolfo, R. (2017b). "Comparative seismic evaluation between numerical analysis and Italian guidelines on cultural heritage applied to the case study of a masonry building compound," in AIP Conference Proceedings (Rhodes), 1863.

Formisano, A., Florio, G., Landolfo, R., and Mazzolani, F. M. (2011). "Numerical calibration of a simplified procedure for the seismic behaviour assessment of Masonry building aggregates," in Proceedings of the 13th International Conference on Civil, Structural and Environmental Engineering Computing (Stirlingshire).

Formisano, A., Florio, G., Landolfo, R., and Mazzolani, F. M. (2015). Numerical calibration of an easy method for seismic behaviour assessment on large scale of masonry building aggregates. Adv. Eng. Softw. 80, 116-138. doi: 10.1016/j.advengsoft.2014.09.013

Formisano, A., and Massimilla, A. (2018). A novel procedure for simplified nonlinear numerical modeling of structural units in Masonry aggregates. Int. J. Archit. Herit. 12, 1162-1170. doi: 10.1080/15583058.2018.15 03365

Fuentes, D. D., Laterza, M., and D’Amato, M. (2019). “Seismic vulnerability and risk assessment of historic constructions: the case of masonry and adobe churches in Italy and Chile," in Proceedings of the 11th International Conference on Structural Analysis of Historical Constructions (Cusco: RILEM Bookseries).

Giuffrè, A. (1993). Safety and Conservation of Historical Centres. The Case of Ortigia (in Italian). Bari: Laterza.

GNDT (1993). Seismic Risk of Public Buildings, Part I: Methodological Issues (in Italian). Rome: CNR-National Group for Defence against Earthquakes.

Grunthal, G. (1998). European Macroseismic Scale 1998. Cahiers du Centre Européen de Géodynamique et de Séismologie, 101. 
Kircher, C. A., Nassar, A. A., Kustu, O., and Holmes, W. T. (1997). Development of building damage functions for earthquake loss estimation. Earthquake Spectra 13, 663-682. doi: 10.1193/1.1585974

Lagomarsino, S., and Giovinazzi, S. (2006). Macroseismic and mechanical models for the vulnerability assessment of current buildings. Bull. Earthquake Eng. 4, 415-443. doi: 10.1007/s10518-006-9024-z

Lagomarsino, S., Penna, A., Galasco, A., and Cattari, S. (2013). TREMURI program: an equivalent frame model for the nonlinear seismic analysis of masonry buildings. Eng. Struct. 56, 1787-1799. doi: 10.1016/j.engstruct.2013.08.002

Magenes, G. (2000). "A method for pushover analysis in seismic assessment of masonry buildings," in Proceedings of the 12th World Conference on Earthquake Engineering. Paper No. 1866 (on CD). (Auckland).

Mallardo, V., Malvezzi, R., Milani, E., and Milani, G. (2008). Seismic vulnerability of historical masonry buildings: a case study in Ferrara. Eng. Struct. 30, 2223-2241. doi: 10.1016/j.engstruct.2007.11.006

Miano, A., Jalayer, F., Ebrahimian, H., and Prota, A. (2018). Cloud to IDA: efficient fragility assessment with limited scaling. Earthquake Eng. Struct. Dyn. 47, 1124-1147. doi: 10.1002/eqe.3009

Miano, A., Sezen, H., Jalayer, F., and Prota, A. (2017). "Performance based comparison of different retrofit methods for reinforced concrete structures," in Proceedings of the 6th ECCOMAS Thematic Conference on Computational Methods in Structural Dynamics and Earthquake Engineering (COMPDYN 2017) (Rhodes).

Ministerial Decree (M.D.) (2018). Updating of Technical Codes for Constructions (in Italian). Official Gazette no. 42 (Rome).

Ministry of Cultural Heritage and Activities (MiBAC) (2011). Guidelines for the Seismic Risk Evaluation and Reduction of the Cultural Heritage - Alignment to the Technical Standards for Constructions (in Italian). Rome.

Mosoarca, M., Onescu, I., Azap, B., Onescu, E., Chieffo, N., and SzitarSirbu, M. (2019). Seismic vulnerability assessment for the historical areas of the Timisoara city, Romania. Eng. Fail. Anal. 101, 86-112. doi: 10.1016/j.engfailanal.2019.03.013

Papa, F., and Zuccaro, G. (2004). MEDEA: A Multimedia and Didactic Handbook for Seismic Damage Evaluation. Potsdam: European Seismological Commission.

Ramírez, E., Lourenço, P. B., and D'Amato, M. (2019). "Seismic assessment of the Matera Cathedral," in SAHC 2018 - 11th International Conference on
Structural Analysis of Historical Constructions (Cusco: Springer), $1346-1354$.

Ramos, L. F., and Lourenco, P. B. (2004). Modeling and vulnerability of historical city centers in seismic areas: a Case Study in Lisbon. Eng. Struct. 26, 1295-1310. doi: $10.1016 /$ j.engstruct.2004.04.008

Senaldi, I., Magenes, G., and Penna, A. (2010). Numerical investigations on the seismic response of masonry building aggregates. Adv. Mater. Res. 133-134, 715-720. doi: 10.4028/www.scientific.net/AMR.133-134.715

Senaldi, I. E., Guerrini, G., Comini, P., Graziotti, F., Penna, A., Beyer, K., et al. (2019). Experimental seismic performance of a half-scale stone masonry building aggregate. Bull. Earthquake Eng. 1-35. doi: 10.1007/s10518-019-00631-2

STA DATA srl. (2018). 3Muri User Manual. Turin.

Valente, M. V., Milani, G., Grande, E., and Formisano, A. (2019). Historical masonry building aggregates: advanced numerical insight for an effective seismic assessment on two row housing compounds. Eng. Struct. 190, 360-379. doi: 10.1016/j.engstruct.2019.04.025

Valluzzi, M. R., Munari, M., Modena, C., Binda, L., Cardani, G., and Saisi, A. (2007). Multilevel approach to the vulnerability analysis of historic buildings in seismic areas-Part 2: analytical interpretation of mechanisms for the vulnerability analysis and the structural improvement. Int. J. Restor. Build. Monum. 13, 427-441. doi: 10.1515/rbm-200 7-6172

Whitman, R. V., Reed, J. W., and Hong, S. T. (1973). "Earthquake damage probability matrices," in Proceedings of the Fifth World Conference on Earthquake Engineering, Vol. 2. (Rome).

Conflict of Interest Statement: The authors declare that the research was conducted in the absence of any commercial or financial relationships that could be construed as a potential conflict of interest.

Copyright (c) 2019 Chiumiento and Formisano. This is an open-access article distributed under the terms of the Creative Commons Attribution License (CC BY). The use, distribution or reproduction in other forums is permitted, provided the original author(s) and the copyright owner(s) are credited and that the original publication in this journal is cited, in accordance with accepted academic practice. No use, distribution or reproduction is permitted which does not comply with these terms. 